\title{
Chapter 8 \\ Spectroscopic Investigation of Shell Pigments from the Family Neritidae (Mollusca: Gastropoda)
}

\author{
Toshiyuki Komura, Hiroyuki Kagi, Makiko Ishikawa, Mana Yasui, \\ and Takenori Sasaki
}

\begin{abstract}
Molluscan shells display a wide variety of pigmentation patterns. The diversity in molluscan shell color reflects the variety of different chemical species in the shell surface. Chemical characteristics of molluscan shell pigments have been extensively investigated, and compounds including porphyrins, polyenes, and melanins were identified as shell pigments. Here, we investigated shell pigments in 24 species in the family Neritidae using Raman spectroscopy. An excitation wavelength of $514.5 \mathrm{~nm}$ revealed two types of Raman spectra. One was characterized by two peaks ranging in wavenumber from $1100-1200$ to $1500-1600 \mathrm{~cm}^{-1}$, which indicate the presence of polyenes. Another type remained unassigned, implying the presence of other pigments such as porphyrins or melanins. The Raman spectra indicated a different distribution of the two types of pigments in shells. The patterns of the Raman spectra had no obvious relationship with taxonomical classification lower than the genus level and typical habitats. Measurement of the Raman spectrum at an excitation wavelength of $442 \mathrm{~nm}$ suggested that the wavelength can distinguish polyenes from other types of pigments.
\end{abstract}

T. Komura $(\bowtie) \cdot$ H. Kagi

Graduate School of Science, The University of Tokyo, Bunkyo-ku, Tokyo, Japan

e-mail: komura@eqchem.s.u-tokyo.ac.jp; kagi@eqchem.s.u-tokyo.ac.jp

M. Ishikawa

Graduate School of Science, The University of Tokyo, Bunkyo-ku, Tokyo, Japan

Faculty of Animal Health Technology, Yamazaki Gakuen University, Hachioji, Tokyo, Japan

e-mail: maki.ishikawa.gm@gmail.com

M. Yasui

Department of Resources and Environmental Engineering, School of Creative Science and

Engineering, Waseda University, Shinjuku-ku, Tokyo, Japan

e-mail: mana@aoni.waseda.jp

T. Sasaki

The University Museum, The University of Tokyo, Bunkyo-ku, Tokyo, Japan

e-mail: sasaki@um.u-tokyo.ac.jp 
Keywords Mollusc $\cdot$ Neritidae $\cdot$ Shell pigment $\cdot$ Polyene $\cdot$ Porphyrin $\cdot$ Raman spectroscopy

\subsection{Introduction}

The phylum Mollusca is the second largest taxon in the animal kingdom. It is very diverse in size, shape, color, habitats, and other traits. The diverse pigmentation patterns on shells are a key trait. Diversity in molluscan shell color reflects the wide variety of chemical species included in the shell. Investigating the origin of shell pigmentation is very important to understand the evolutionary history of Mollusca (Williams 2017). Furthermore, chemical speciation of shell pigment molecules could provide insight into the interaction of pigment molecules with other shell components (Hedegaard et al. 2006), which is important for the better understanding of biomineralization during shell formation.

Shell pigments have been extensively investigated (Williams 2017; Ishikawa et al. 2013 and references therein). Comfort (1949a, b) reported the presence of porphyrin compounds in several groups of gastropods including the family Neritidae (described later) using ultraviolet fluorescence and absorption chromatography. Subsequently, the presence of polyene compounds was reported using Raman spectroscopy. For example, Hedegaard et al. (2006) estimated the chain length of conjugated polyenes and discussed the chemical modification of polyenes contained in the shell of the gastropod Cypraea moneta (Cypraeidae). Polyene pigments were observed in various taxa. However, the target samples used in previous studies were limited to common shells with strong colors. Here, we comprehensively studied the family Neritidae and conducted a preliminary study to detect porphyrin pigments using Raman spectroscopy. The family Neritidae comprises small- or medium-sized snails that inhabit a wide variety of shallow-water environments such as brackish areas and intertidal rocky zones. The family is characterized by clear and vivid color bands (Fig. 8.1), which make spectroscopic analysis easy to perform. Their various habitats are expected to have an effect on pigmentation because shell colors are affected by environmental factors (e.g., Sokolova and Berger 2000).

\subsection{Materials and Methods}

We investigated 24 species from 5 genera of the family Neritidae by using Raman spectroscopy (Table 8.1). Raman spectra were obtained from each differently colored area using an exposure time of $10 \mathrm{~s}$ for each measurement. Ten spectra were obtained for each area. Estimated energy resolution ranged from 1 to $2 \mathrm{~cm}^{-1}$. Two Raman spectrometers with different excitation wavelengths (514.5 and $442 \mathrm{~nm}$ ) were used (Table 8.2). The excitation wavelength of $514.5 \mathrm{~nm}$ has been previously demonstrated to detect polyenes. The excitation wavelength of $442 \mathrm{~nm}$ is near the Soret maxima of porphyrins and thus is expected to excite porphyrins that are 


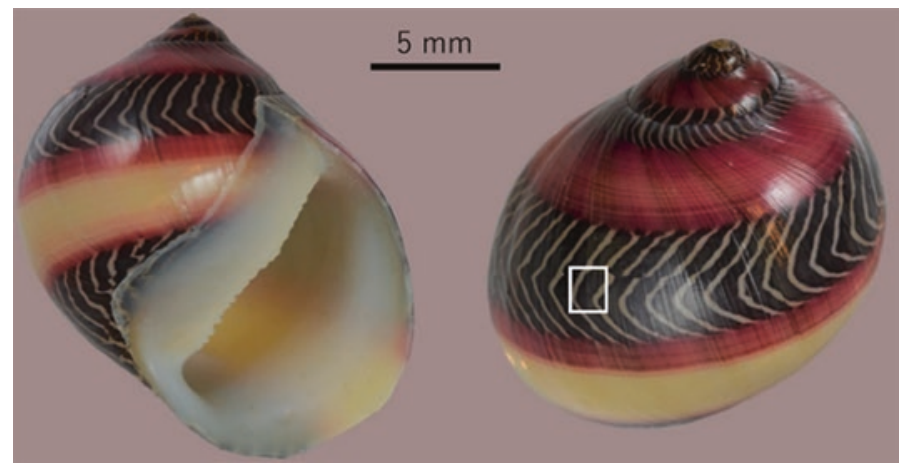

Fig. 8.1 Neritina waigiensis in the family Neritidae. A section of the shell denoted by the white square was used for Raman analysis (see Fig. 8.3)

Table 8.1 Collection numbers, species, locality, and typical habitats of the investigated samples

\begin{tabular}{|c|c|c|c|}
\hline $\begin{array}{l}\text { Coll. } \\
\text { number }\end{array}$ & Species & Locality & Typical habitat \\
\hline $\begin{array}{l}\text { RM } \\
32906\end{array}$ & $\begin{array}{l}\text { Clithon oualaniense (Lesson, } \\
\text { 1831) }\end{array}$ & $\begin{array}{l}\text { Bohol Island, } \\
\text { Philippines }\end{array}$ & $\begin{array}{l}\text { Brackish, on sandy or } \\
\text { muddy substrate }\end{array}$ \\
\hline $\begin{array}{l}\text { RM } \\
32907\end{array}$ & $\begin{array}{l}\text { Clithon (Pictoneritina) } \\
\text { chlorostoma (Broderip, 1833) }\end{array}$ & $\begin{array}{l}\text { Ishigaki Island, } \\
\text { Japan }\end{array}$ & Under rocks, in estuaries \\
\hline $\begin{array}{l}\text { RM } \\
32908\end{array}$ & Clithon cryptum (Eichhorst, 2016) & $\begin{array}{l}\text { Amami Island, } \\
\text { Japan }\end{array}$ & Under rocks, in estuaries \\
\hline $\begin{array}{l}\text { RM } \\
32909\end{array}$ & $\begin{array}{l}\text { Nerita (Amphinerita) insculpta } \\
\text { (Récluz, 1841) }\end{array}$ & $\begin{array}{l}\text { Okinawa Island, } \\
\text { Japan }\end{array}$ & Intertidal, on rocks \\
\hline $\begin{array}{l}\text { RM } \\
32910\end{array}$ & $\begin{array}{l}\text { Nerita (Cymostyla) tristis (Pilsbry, } \\
\text { 1901) }\end{array}$ & $\begin{array}{l}\text { Amami Oshima } \\
\text { Island, Japan }\end{array}$ & Intertidal, on rocks \\
\hline $\begin{array}{l}\text { RM } \\
32911\end{array}$ & $\begin{array}{l}\text { Nerita (Cymostyla) striata } \\
\text { (Burrow, 1815) }\end{array}$ & $\begin{array}{l}\text { Okinawa Island, } \\
\text { Japan }\end{array}$ & Intertidal, on rocks \\
\hline $\begin{array}{l}\text { RM } \\
32912\end{array}$ & $\begin{array}{l}\text { Nerita (Ritena) plicata (Linnaeus, } \\
1758 \text { ) }\end{array}$ & Ikema Island, Japan & Intertidal, on rocks \\
\hline $\begin{array}{l}\text { RM } \\
32913\end{array}$ & $\begin{array}{l}\text { Nerita (Ritena) costata (Gmelin, } \\
\text { 1791) }\end{array}$ & $\begin{array}{l}\text { Amami Oshima } \\
\text { Island, Japan }\end{array}$ & Intertidal, on rocks \\
\hline $\begin{array}{l}\text { RM } \\
32914\end{array}$ & $\begin{array}{l}\text { Nerita (Theliostyla) picea (Récluz, } \\
\text { 1841) }\end{array}$ & Australia & Uncertain \\
\hline $\begin{array}{l}\text { RM } \\
32915\end{array}$ & $\begin{array}{l}\text { Nerita (Theliostyla) exuvia } \\
\text { (Linnaeus, 1758) }\end{array}$ & $\begin{array}{l}\text { Cebu Island, } \\
\text { Philippines }\end{array}$ & Intertidal, on rocks \\
\hline $\begin{array}{l}\text { RM } \\
32916\end{array}$ & $\begin{array}{l}\text { Nerita (Theliostyls) albicala } \\
\text { (Linnaeus, 1758) }\end{array}$ & $\begin{array}{l}\text { Amami Island, } \\
\text { Japan }\end{array}$ & Intertidal, on rocks \\
\hline $\begin{array}{l}\text { RM } \\
32917\end{array}$ & $\begin{array}{l}\text { Nerita (Argonerita) signata } \\
\text { (Lamarck, 1822) }\end{array}$ & $\begin{array}{l}\text { Bohol Island, } \\
\text { Philippines }\end{array}$ & Intertidal, on rocks \\
\hline $\begin{array}{l}\text { RM } \\
32918 \\
\end{array}$ & $\begin{array}{l}\text { Nerita (Argonerita) chammaeleon } \\
\text { (Linnaeus, 1758) }\end{array}$ & $\begin{array}{l}\text { Ishigaki Island, } \\
\text { Japan }\end{array}$ & Intertidal, on rocks \\
\hline $\begin{array}{l}\text { RM } \\
32919\end{array}$ & $\begin{array}{l}\text { Nerita (Linnerita) incerta (von } \\
\text { dem Busch, 1844) }\end{array}$ & $\begin{array}{l}\text { Zamami Island, } \\
\text { Japan }\end{array}$ & Intertidal, on rocks \\
\hline
\end{tabular}


Table 8.1 (continued)

\begin{tabular}{|c|c|c|c|}
\hline $\begin{array}{l}\text { Coll. } \\
\text { number }\end{array}$ & Species & Locality & Typical habitat \\
\hline $\begin{array}{l}\text { RM } \\
32920\end{array}$ & $\begin{array}{l}\text { Neritina (Linnerita) rumphi } \\
\text { (Récluz, 1841) }\end{array}$ & $\begin{array}{l}\text { Malakal Island, } \\
\text { Palau }\end{array}$ & Intertidal, on rocks \\
\hline $\begin{array}{l}\text { RM } \\
32921\end{array}$ & $\begin{array}{l}\text { Neritina (Linnerita) polita } \\
\text { (Linnaeus, 1758) }\end{array}$ & $\begin{array}{l}\text { Okinawa Island, } \\
\text { Japan }\end{array}$ & $\begin{array}{l}\text { Intertidal, on rocks near } \\
\text { sand }\end{array}$ \\
\hline $\begin{array}{l}\text { RM } \\
32922\end{array}$ & $\begin{array}{l}\text { Neritina (Neritina) pulligera } \\
\text { (Linnaeus, 1767) }\end{array}$ & $\begin{array}{l}\text { Okinawa Island, } \\
\text { Japan }\end{array}$ & On rocks in rivers \\
\hline $\begin{array}{l}\text { RM } \\
32923\end{array}$ & $\begin{array}{l}\text { Neritina (Vittina) paralela } \\
\text { (Röding, 1798) }\end{array}$ & $\begin{array}{l}\text { Cebu Island, } \\
\text { Philippines }\end{array}$ & Brackish area \\
\hline $\begin{array}{l}\text { RM } \\
32924\end{array}$ & $\begin{array}{l}\text { Neritina (Vittina) waigiensis } \\
\text { (Lesson, 1831) }\end{array}$ & $\begin{array}{l}\text { Cebu Island, } \\
\text { Philippines }\end{array}$ & Mangrove swamp \\
\hline $\begin{array}{l}\text { RM } \\
32925\end{array}$ & $\begin{array}{l}\text { Neritina (Vittina) turritta (Gmelin, } \\
\text { 1791) }\end{array}$ & $\begin{array}{l}\text { Cebu Island, } \\
\text { Philippines }\end{array}$ & $\begin{array}{l}\text { On mud in mangrove } \\
\text { swamp }\end{array}$ \\
\hline $\begin{array}{l}\text { RM } \\
32926\end{array}$ & $\begin{array}{l}\text { Neripteron (Dostia) cornucopia } \\
\text { (Benson, } 1836 \text { ) }\end{array}$ & $\begin{array}{l}\text { Cebu Island, } \\
\text { Philippines }\end{array}$ & $\begin{array}{l}\text { Brackish area and } \\
\text { mangrove swamp }\end{array}$ \\
\hline $\begin{array}{l}\text { RM } \\
32927\end{array}$ & $\begin{array}{l}\text { Smaragdia rangiana (Récluz, } \\
1842 \text { ) }\end{array}$ & $\begin{array}{l}\text { Balicasag Island, } \\
\text { Philippines }\end{array}$ & On seagrasses \\
\hline $\begin{array}{l}\text { RM } \\
32928\end{array}$ & Neritodryas dubia (Gmelin, 1791) & $\begin{array}{l}\text { Cebu Island, } \\
\text { Philippines }\end{array}$ & Intertidal, brackish area \\
\hline $\begin{array}{l}\text { RM } \\
32929\end{array}$ & Neritodryas sp. & $\begin{array}{l}\text { Cebu Island, } \\
\text { Philippines }\end{array}$ & Intertidal, brackish area \\
\hline
\end{tabular}

Scientific names and typical habitats follow the designation schemes of Tsuchiya and Kano (2017) and Eichhorst (2016)

Table 8.2 Excitation wavelength, laser source, laser power, calibration standard, and objective lens magnification data of the two Raman spectrometers

\begin{tabular}{l|l|l|l|l}
\hline $\begin{array}{l}\text { Excitation wavelength } \\
(\mathrm{nm})\end{array}$ & $\begin{array}{l}\text { Laser } \\
\text { source }\end{array}$ & $\begin{array}{l}\text { Laser power } \\
(\mathrm{mW})\end{array}$ & $\begin{array}{l}\text { Calibration } \\
\text { standard }\end{array}$ & $\begin{array}{l}\text { Objective lens } \\
\text { magnification }\end{array}$ \\
\hline 514.5 & $\begin{array}{l}\mathrm{Ar} \\
\text { laser }\end{array}$ & 30 & Naphthalene & $\times 20$ \\
\hline 442 & $\begin{array}{l}\mathrm{He}-\mathrm{Cd} \\
\text { laser }\end{array}$ & 120 & Silicon & $\times 20$ \\
\hline
\end{tabular}

Laser power could be attenuated through the optical paths for both instruments

present in the mollusc shell (Comfort 1949a). We performed intact shell surface analysis without chemical treatments. The samples examined were registered in The University Museum, The University of Tokyo. 


\subsection{Results and Discussion}

\subsubsection{Raman Spectra at $514.5 \mathrm{~nm}$}

Figure 8.2 shows representative Raman spectra obtained from yellow, red, and black color bands of $N$. waigiensis. The Raman spectra of the black and red parts were similar, while the spectrum of the yellow part was markedly different from both. The spectrum obtained from the yellow part was characterized by two peaks with wavenumbers ranging from $1100-1200 \mathrm{~cm}^{-1}\left(\nu_{5}\right)$ to $1500-1600 \mathrm{~cm}^{-1}\left(\nu_{1}\right)$. These two peaks are assigned to polyene pigments contained in the shell (e.g., Bergamonti et al. 2013). These polyene-type spectra were obtained from the species listed in Table 8.3. While Raman shifts of $\nu_{5}$ and $\nu_{1}$ varied in all species, the observed values were within a certain range.

The spectra obtained from red and black parts of $N$. waigiensis had no obvious peaks that could be assigned to polyenes. This type of spectrum was also obtained from the species listed in Table 8.4. Similar spectra from the gastropod Clunculus pharaonius (Trochidae) were reported by Merlin and Delé-Dubois (1986) and Williams et al. (2016). The red and black pigments of $C$. pharaonius were identified as uroporphyrin and eumelanin, respectively, using high-performance liquid chromatography (Williams et al. 2016). However, the authors argued that the Raman spectra did not convey any definitive information concerning shell pigments, and it

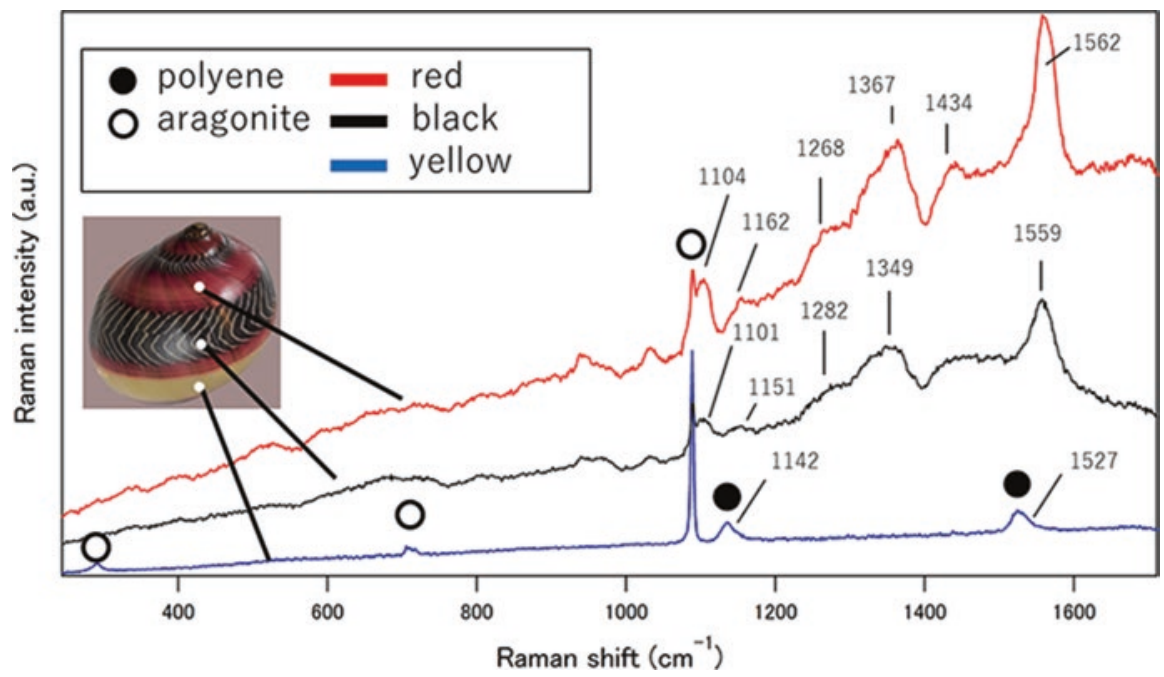

Fig. 8.2 Raman spectra obtained from each color band of $N$. waigiensis using $514.5 \mathrm{~nm}$ excitation. White circles in the figure indicate measurement points for Raman analysis 
Table 8.3 Colors and wavenumbers of the $\nu_{5}$ and $\nu_{1}$ peaks using the $514.5 \mathrm{~nm}$ excitation from species containing polyenes

\begin{tabular}{|c|c|c|c|}
\hline Species & Color & $\begin{array}{l}\nu_{5} \\
\left(\mathrm{~cm}^{-1}\right)\end{array}$ & $\begin{array}{l}\nu_{1} \\
\left(\mathrm{~cm}^{-1}\right)\end{array}$ \\
\hline Clithonoualaniense (Lesson, 1831) & Pale yellow & 1139 & 1532 \\
\hline Nerita (Amphinerita) insculpta (Récluz, 1841) & Black & 1138 & 1528 \\
\hline $\begin{array}{l}\text { Nerita (Linnerita) incerta (von dem Busch, } \\
\text { 1844) }\end{array}$ & Green & 1138 & 1526 \\
\hline Nerita (Cymostyla) tristis (Pilsbry, 1901) & Deep green & 1138 & 1530 \\
\hline Nerita (Cymostyla) striata (Burrow, 1815) & Black & 1135 & 1525 \\
\hline Nerita (Cymostyla) striata (Burrow, 1815) & Light green & 1136 & 1527 \\
\hline Nerita (Ritena) plicata (Linnaeus, 1758) & Black & 1135 & 1524 \\
\hline Nerita (Argonerita) signata (Lamarck, 1822) & Red & 1133 & 1523 \\
\hline $\begin{array}{l}\text { Nerita (Argonerita) chammaeleon (Linnaeus, } \\
1758 \text { ) }\end{array}$ & Black & 1138 & 1524 \\
\hline Nerita (Theliostyls) albicilla (Linnaeus, 1758) & Deep green & 1137 & 1527 \\
\hline Neritina (Linnerita) rumphii (Récluz, 1841) & Black & 1136 & 1526 \\
\hline Neritina (Linnerita) rumphii (Récluz, 1841) & Green & 1137 & 1525 \\
\hline Neritina (Linnerita) polita (Linnaeus, 1758) & Deep green & 1135 & 1524 \\
\hline Neritina (Linnerita) polita (Linnaeus, 1758) & Green & 1135 & 1524 \\
\hline Neritina (Neritina) pulligera (Linnaeus, 1767) & Deep green & 1138 & 1528 \\
\hline Neritina (Neritina) pulligera (Linnaeus, 1767) & Orange & 1139 & 1530 \\
\hline Neritina (Vittina) waigiensis (Lesson, 1831) & Yellow & 1142 & 1527 \\
\hline Smaragdia rangiana (Récluz, 1842) & Green & 1139 & 1534 \\
\hline Nerita (Ritena) costata (Gmelin, 1791) & $\begin{array}{l}\text { Black (between spiral } \\
\text { ribs) }\end{array}$ & 1134 & 1524 \\
\hline
\end{tabular}

was quite unclear whether the obtained spectra were assignable to uroporphyrin or eumelanin included in the shell. Presently, we also could not conclusively identify shell pigment from the Raman spectra. However, the difference in chemical origins of the black and red pigmentations of $N$. waigiensis from that of yellow pigmentation is a novel finding. It is worth noting that the Raman peaks obtained from red and black regions of $N$. waigiensis appeared at a similar frequency to those in the spectrum of eumelanin reported by Mbonyiryivuze et al. (2015). It is conceivable that the peaks we observed were due to background fluorescence.

Shell pigmentation may be relevant to taxonomical classification (Comfort 1949a, Williams 2017). However, the patterns and peak wavenumber of the Raman spectra (Tables 8.1, 8.2, and 8.3) had no obvious relationship with the taxonomical classification at the genus or lower level or with typical habitats. Different types of spectra could be observed even in the same individuals.

We fabricated the shell section perpendicular to the apertural margin of $N$. waigiensis (Fig. 8.3). The thickness of red- and black-colored layers was approximately $30 \mu \mathrm{m}$. The Raman spectra obtained from five points are shown in Fig. 8.4. No obvious peaks assignable to polyenes were observed from points 1 to 2 . Two weak peaks assignable to polyenes were detected at point 3 . The obtained spectra 
8 Spectroscopic Investigation of Shell Pigments from the Family Neritidae (Mollusca...

Table 8.4 Colors and Raman shifts of representative peaks obtained at $514.5 \mathrm{~nm}$ excitation wavelength from species displaying other spectra

\begin{tabular}{|c|c|c|}
\hline Species & Color & $\begin{array}{l}\text { Raman shifts of representative } \\
\text { peak }\left(\mathrm{cm}^{-1}\right)\end{array}$ \\
\hline Clithon oualaniense (Lesson, 1831) & Black & 1562 \\
\hline $\begin{array}{l}\text { Clithon (Pictoneritina) chlorostoma } \\
\text { (Broderip, 1833) }\end{array}$ & Black & 1562 \\
\hline Clithon cryptum (Eichhorst, 2016) & Black & 1566 \\
\hline $\begin{array}{l}\text { Nerita (Linnerita) incerta (von dem } \\
\text { Busch, 1844) }\end{array}$ & Deep green & 1562 \\
\hline Nerita (Theliostyla) picea (Récluz, 1841) & Black & 1560 \\
\hline $\begin{array}{l}\text { Nerita (Theliostyla) exuvia (Linnaeus, } \\
\text { 1758) }\end{array}$ & Black & 1548 \\
\hline $\begin{array}{l}\text { Neripteron (Dostia) cornucopia (Benson, } \\
1836 \text { ) }\end{array}$ & Deep green & 1559 \\
\hline $\begin{array}{l}\text { Neritina (Vittina) waigiensis (Lesson, } \\
\text { 1831) }\end{array}$ & Red & 1562 \\
\hline $\begin{array}{l}\text { Neritina (Vittina) waigiensis (Lesson, } \\
\text { 1831) }\end{array}$ & Black & 1557 \\
\hline Neritina (Vittina) turritta (Gmelin, 1791) & Black & 1566 \\
\hline $\begin{array}{l}\text { Neritina (Vittina) parallella (Röding, } \\
\text { 1798) }\end{array}$ & Black & 1558 \\
\hline Neritodryas dubia (Gmelin, 1791) & Deep purple & 1560 \\
\hline Neritodryas sp. & Red & 1560 \\
\hline Neritodryas sp. & Black & 1565 \\
\hline Nerita (Ritena) costata (Gmelin, 1791) & $\begin{array}{l}\text { Black (on spiral } \\
\text { ribs) }\end{array}$ & 1554 \\
\hline
\end{tabular}
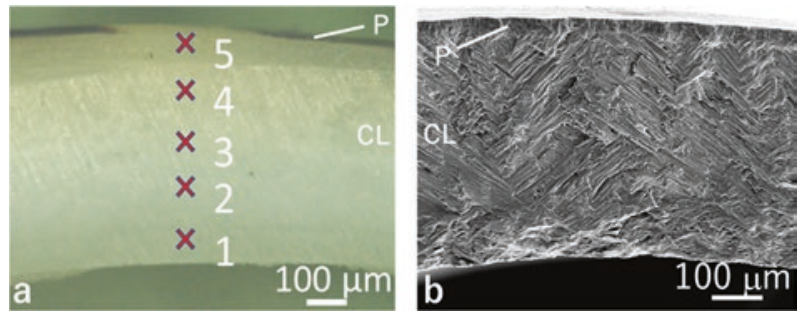

Fig. 8.3 (a) A section perpendicular to the apertural margin of $N$. waigiensis. The black and yellow patterns on the shell exterior are visible on the upper side of the figure. The numbers $1-5$ indicate measured points. (b) Scanning electron microscopy image of the section of $N$. waigiensis. The multilayered structure of the shell is evident. The outermost region is a prismatic layer $(\mathrm{P})$ that corresponds to the colored layer in (a). The inner layer has a crossed-lamellar structure (CL). These two figures were obtained from different individuals of $N$. waigiensis

raise the possibility that the concentration of polyenes increases continuously from the interior of the shell to the exterior surface. In contrast, black and red pigmentation appeared only in the narrow range on the surface, indicating that their distributions are quite different from the distribution of polyenes. 


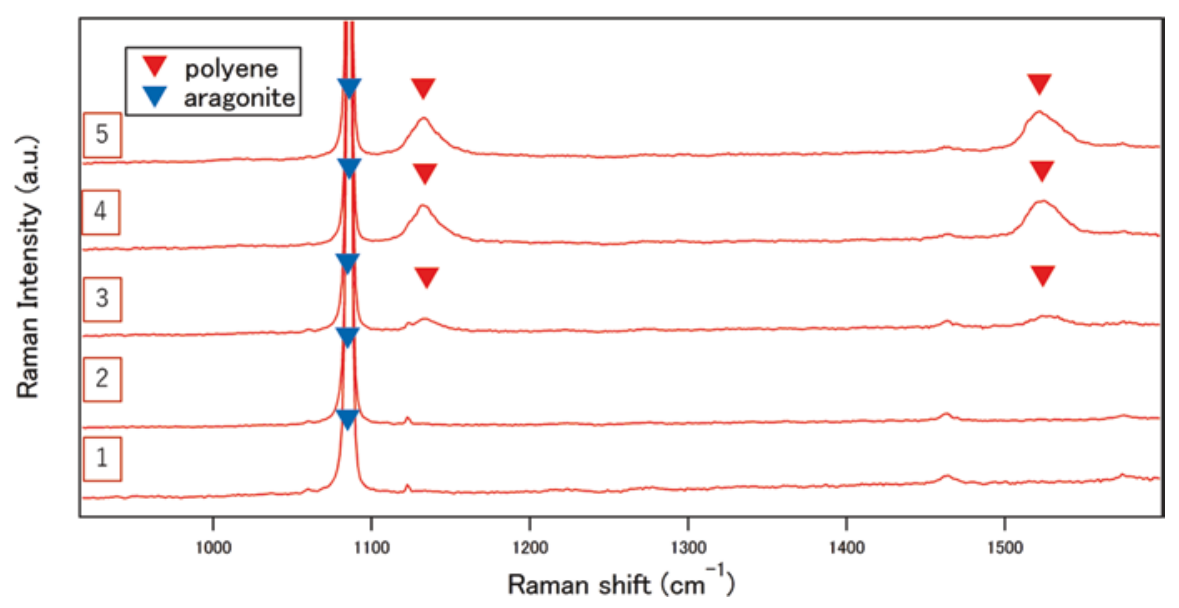

Fig. 8.4 Raman spectrum obtained from each measured point in Fig. 8.3

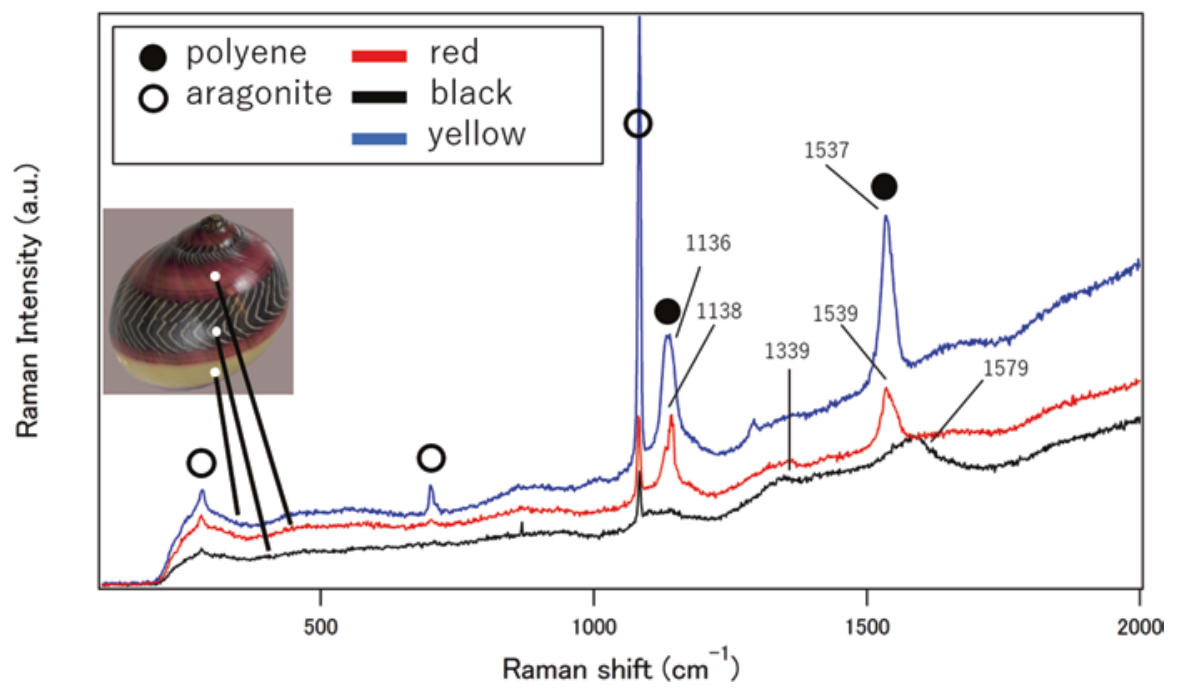

Fig. 8.5 Raman spectrum obtained from each color band of $N$. waigiensis using the $442 \mathrm{~nm}$ excitation wavelength. The white circles in the figure indicate the measurement points for Raman analysis

\subsubsection{Raman Spectra at $442 \mathrm{~nm}$ Excitation}

Figure 8.5 shows Raman spectra obtained from $N$. waigiensis using the $442 \mathrm{~nm}$ excitation wavelength. Clear peaks assignable to polyenes were observed from the yellow and red parts of the shell surface, but not from the black part. Polyene-type 
spectrum from the red part may be attributed to the polyenes of the yellow part existing just under the red color band on the surface. Williams et al. (2016) argued that it is difficult to distinguish polyenes from porphyrins only by the Raman spectra. However, our results suggest that polyenes can be distinguished from other pigments because the background fluorescence was relatively low compared to that for the peak heights at $\nu_{5}$ and $\nu_{1}$.

\subsection{Conclusions}

Analysis using the $514.5 \mathrm{~nm}$ excitation wavelength demonstrated that the pigmentation in the family Neritidae has at least two types of origins: polyenes and other unknown pigments such as porphyrins or melanins. The data from a shell section of $N$. waigiensis suggest that these two types of pigments are distributed in a different manner in the section. The patterns of the Raman spectra did not display obvious relationships with taxonomical classification and habitats. The Raman spectra obtained using the $442 \mathrm{~nm}$ excitation wavelength suggest that polyenes can be distinguished from other pigments by the presence of strong peaks of $\nu_{5}$ and $\nu_{1}$. However, definitive information on shell pigments was difficult using only Raman spectroscopy. Other analytical techniques such as high-performance liquid chromatography could be needed and will be studied.

Acknowledgment We thank Dr. Natsuhiko Sugimura from the Research Support Center at Waseda University for providing support for the measurement of the Raman spectra.

\section{References}

Bergamonti L, Bersani D, Mantovan S, Lottici PP (2013) Micro-Raman investigation of pigments and carbonate phases in corals and molluscan shells. Eur J Mineral 25:845-853

Comfort A (1949a) Acid-soluble pigments of shells. 1. The distribution of porphyrin fluorescence in molluscan shells. Biochem J 44:111-117

Comfort A (1949b) Acid-soluble pigments of shells. 4. Identification of shell porphyrins with particular reference to conchoporphyrin. Biochem J 45:208-210

Eichhorst TE (2016) Neritidae in the world. ConchBooks, Harxheim

Hedegaard C, Bardeau J-F, Chateigner D (2006) Molluscan shell pigments: an in situ resonance Raman study. J Molluscan Stud 72:157-162

Ishikawa M, Kagi H, Sasaki T, Endo K (2013) Current trend of research in molluscan shell pigments. Earth Mon 35(12):712-719 (In Japanese)

Mbonyiryivuze A, Omollo I, Ngom BD, Mwakikunga B, Dhlamini SM, Park E, Maaza M (2015) Natural dye sensitizer for Grätzel cells: Sepia Melanin. Phys Mater Chem 3(1):1-6

Merlin JC, Delé-Dubois ML (1986) Resonance Raman characterization of polyacetylenic pigments in the calcareous skeleton. Comp Biochem Physiol 84B(1):97-103 
Sokolova IM, Berger VJ (2000) Physiological variation related to shell colour polymorphism in White Sea Littorina saxatilis. J Exp Mar Biol Ecol 245:1-23

Tsuchiya K, Kano Y (2017) Family Neritidae. In: Okutani T (ed) Marine Mollusks in Japan, 2nd edn. Tokai University Press, Tokyo

Williams ST (2017) Molluscan shell colour. Biol Rev 92:1039-1058

Williams ST, Ito S, Wakamatsu K, Goral T, Edwards NP, Wogelius RA et al (2016) Identification of shell colour pigments in marine snails Clanculus pharaonius and C. margaritarius (Trochoidea; Gastropoda). PLoSONE 11(7):e0156664

Open Access This chapter is licensed under the terms of the Creative Commons Attribution 4.0 International License (http://creativecommons.org/licenses/by/4.0/), which permits use, sharing, adaptation, distribution and reproduction in any medium or format, as long as you give appropriate credit to the original author(s) and the source, provide a link to the Creative Commons license and indicate if changes were made.

The images or other third party material in this chapter are included in the chapter's Creative Commons license, unless indicated otherwise in a credit line to the material. If material is not included in the chapter's Creative Commons license and your intended use is not permitted by statutory regulation or exceeds the permitted use, you will need to obtain permission directly from the copyright holder.

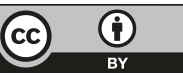

